\title{
Epidemiologia e distribuição espacial da mortalidade relacionada à doença de Chagas no Brasil, 1999 a 2007
} Epidemiology and spatial distribution of mortality related to
Chagas disease in Brazil, 1999 to 2007

Dissertação: Francisco Rogerlândio Martins-Melo

Orientador: Jorg Heukelbach

\section{Resumo}

A doença de Chagas é uma Doença Tropical Negligenciada e um problema de saúde pública, com significativas implicações socioeconômicas na maioria dos países latino-americanos, incluindo o Brasil. Este estudo objetivou caracterizar a magnitude e os padrões da mortalidade relacionada à doença de Chagas no Brasil. Foi realizado estudo analítico com dados de mortalidade obtidos do Sistema de Informação sobre Mortalidade do Ministério da Saúde (SIM/DATASUS/MS). Analisaram-se todos os óbitos ocorridos no Brasil entre 1999 e 2007, nos quais a doença de Chagas foi mencionada como causa básica ou associada de morte. Calcularam-se os coeficientes de mortalidade específicos e a mortalidade proporcional para analisar as tendências temporais por meio de regressão polinomial. Fatores associados ao óbito pela doença de Chagas foram investigados por meio da comparação com os óbitos gerais. Para a análise de autocorrelação espacial com os municípios como unidade de observação foram utilizados os métodos: Moran global, Getis-Ord General G, Moran local e estatística Gi* Entre 1999 e 2007, houve 53.930 óbitos relacionados à doença de Chagas no Brasil (44.543 como causa básica e 9.387 como causa associada), com coeficiente médio de mortalidade de 3,78/100.000 habitantes e mortalidade proporcional de $0,6 \%$. Durante o período de estudo, a mortalidade apresentou tendência de declínio a nível nacional $(p=0,011)$, porém com padrões diferenciados entre as regiões. Observou-se redução da mortalidade nas regiões Centro-Oeste $(p=0,001)$, Sudeste $(p=0,007)$ e Sul $(p=0,028)$, mas a região Nordeste apresentou tendência de crescimento $(p=0,047)$ e a Norte de estabilidade da mortalidade $(p=0,309)$. Na análise multivariada foram independentemente associados à mortalidade: idade maior de 30 anos (odds ratio - OR ajustada=10,60; IC95\% 9,90-11,33; $\mathrm{p}<0,001$ ); residir nos estados de Minas Gerais, Goiás e Distrito Federal (OR ajustada=4,89; IC95\% 4,80-4,98; p<0,001); não morar em capital de estado (OR ajustada=1,04; IC95\% $1,02-1,06 ; p<0,001$ ) e sexo masculino (OR ajustada=1,02; IC95\% 1,00-1,03; $p=0,045$ ). As principais causas associadas à doença de Chagas como causa básica foram as complicações diretas do envolvimento cardíaco, incluindo os transtornos de condução/arritmias $(41,4 \%)$ e a insuficiência cardíaca (37,7\%). As doenças cerebrovasculares (13,2\%), isquêmicas do coração (13,2\%) e hipertensivas $(9,3 \%)$ foram as principais causas básicas nos óbitos em que a doença de Chagas foi causa associada. A análise espacial identificou um extenso agregado espacial (cluster) de alto risco para mortalidade relacionada à doença de Chagas envolvendo oito estados na região central do Brasil e mais quatro clusters menores. Apesar do declínio da mortalidade relacionada à doença de Chagas no Brasil, esta continua sendo uma importante causa de morte em áreas endêmicas e com marcantes diferenças regionais. Com o declínio da transmissão vetorial, as deficiências no sistema público para a sua prevenção, controle e tratamento, principalmente nas regiões Norte e Nordeste, precisam ser superadas. O desafio é garantir acesso adequado aos serviços de saúde e assistência social para o grande número de indivíduos com doença de Chagas na fase crônica, que se acumularam durante as últimas décadas.

Palavras-chave: Doença de Chagas; mortalidade; epidemiologia; distribuição espacial da população; estudos de séries temporais. 


\section{Abstract}

Chagas' disease is a Neglected Tropical Disease and a public health problem, with significant socioeconomic impact in most Latin American countries, including Brazil. This study aimed to characterize the magnitude and patterns of mortality associated with Chagas' disease in Brazil. An analytical study was conducted, based on mortality data obtained from the Mortality Information System of the Ministry of Health. We studied all deaths occurred in Brazil from 1999 to 2007, in which Chagas' disease was mentioned as underlying or associated cause of death. We calculated mortality rates and proportional mortality and described time trends, using polynomial regression. Factors associated with death from Chagas' disease were identified, as compared to deaths by other causes. For spatial analysis with municipalities as observation units, we used the following methods: Global Moran, Getis-Ord General G, local Moran and Gi* statistic. Between 1999 and 2007, 53,930 deaths occurred related to Chagas' disease in Brazil (44,543 was underlying cause of death, and 9,387 associated cause), with a mean mortality of $3.78 / 100,000 /$ year, and a proportional mortality of $0.6 \%$. Mortality showed a declining trend at national level $(p=0.011)$, but with different patterns between regions. There was a reduction of mortality in the Central West $(p=0.001)$, Southeast $(p=0.007)$ and South $(p=0.028)$, whereas the Northeast showed an increasing trend $(p=0.047)$, and the North a tendency of stabilization of mortality $(\mathrm{p}=0.309)$. In multivariable analysis, factors independently associated with mortality were: age over 30 years (adjusted odds ratio - OR=10.60; 95\% Cl 9.90-11.33; $p<0.001$ ); residence in the states of Minas Gerais, Goiás and Distrito Federal (adjusted $\mathrm{OR}=4.89 ; 95 \% \mathrm{Cl} 4.80-4.98 ; \mathrm{p}<0.001$ ); not living in a state capital (adjusted OR=1.04; $95 \% \mathrm{Cl} 1.02-$ 1.06; $\mathrm{p}<0 ; 001$ ); and male sex (adjusted $\mathrm{OR}=1.02 ; 95 \% \mathrm{Cl} 1.00-1.03 ; \mathrm{p}=0.045$ ). The main conditions associated with Chagas' disease as underlying cause of death were cardiac complications, such as conduct disorders/arrhythmias (41.4\%) and heart failure (37.7\%). Cerebrovascular complications (13.2\%), ischemic heart disease (13.2\%) and hypertensive disorders (9.3\%) were the main underlying causes of death in which Chagas' disease was an associated cause. Spatial analysis identified a major cluster of high risk for mortality related to Chagas' disease involving eight states in the central region of Brazil, and four smaller clusters of high risk in the surrounding area. Despite the decline in mortality associated with Chagas' disease in Brazil, it remains an important cause of death in endemic areas and with marked regional differences. With decreasing importance of vector-borne transmission, the deficiencies of the public system in prevention, control and treatment, mainly in North and Northeast regions, remain a challenge. Adequate access to health services and social assistance need to be guaranteed for the large number of individuals with chronic Chagas' disease that have accumulated during the last decades.

Keywords: Chagas disease; mortality; epidemiology; residence characteristics; time series studies. 